\title{
Trends in Geoinformatics Education
}

\author{
Markéta Potůčková \\ Department of Applied Geoinformatics and Cartography \\ Faculty of Science, Charles University in Prague \\ E-mail: mpot@natur.cuni.cz
}

\section{Introduction}

Recent trends in Global Positioning Systems (GPS), Geographic Information Systems (GIS), photogrammetry, remote sensing and communication technologies require changes in surveying and related educational programs dealing with geoinformation, such as geography, environmental engineering, forest engineering and geology. Changes in structure and format of University curricula across Europe within the past few years reflect this need as well as a diminishing number of survey engineering and geoinformatics students in some countries. Multi-disciplinary education in information technologies (IT), management or economics and geoinformatics can increase employment opportunities in some labour markets.

The terms 'geoinformatics' or 'geomatics' are used interchangeably in some university programs. The definition of both terms has not been standardized to-date. In the context of this paper, geoinformatics is the science dealing with the development and management of databases of spatial data, their analysis, modeling and presentation, and development and integration of computer tools and software for solving these tasks. The term Geomatics originated in Canada in the 60's includes disciplines of spatial data acquisition in addition (Wikipedia).

Geoinformatics curricula at universities with a long tradition in geodesy and cartography education are usually built on solid training in mathematics, physics, programming, computer graphics, and web-applications. This paper focuses on educational models, not common in Central Europe (project-based learning at Aalborg University, Denmark and internationally oriented education at ITC, the Netherlands).

\section{Current trends in Geoinformatics education}

Albeit specifics of some subjects to a given country, especially in cadastre and land management, common general trends can be identified (Enemark, 2005, Höhle, 2006):

- As the amount of information increases, it is necessary to concentrate on 'core knowledge' within each subject. Students should be given references relevant to their field of interest and understand the technology and interpretation of results, - while using modern, easy-to-use systems.

- Traditional focus on professional and technical skills (knowing how) is changing into educational models which expose students to modern technologies and teach how to keep the knowledge up-to-date and solve problems on a scientific basis. 
- Learning management skills in order to meet the needs of customers and to adopt changes in technology developments in the context of a changing social and economic structures of the society.

- Adopting e-Learning as part of a university education. Lectures and exercises are supplemented with presentations, and interactive educational materials on the Internet as well as on-line test and assessments.

- Offering Geoinformatics courses to international students by teaching in English, as shown by some European universities (e.g. TU Berlin, Stuttgart University of Applied Sciences). This could be a possible mitigation measure to decreasing numbers of students enrolled in Geoinformatics in some European countries.

- In recognition of the concept of continuing professional development, or lifelong learning, universities do not concentrate on education of undergraduate and Ph.D. students only, but offer refresher courses on different subjects and at different levels. The use of eLearning enables enrolment of professionals as their time and possibility of attending courses are limited.

\section{Forms of Education}

In most Central European Countries education in Land Surveying and Mapping has been established between the World Wars. Master degree programs take 4-5 years, postgraduate studies 3 years. The EU countries signed the Bologna declaration in 1999. It recommends implementation of the three degree structure for university education, - Bachelor of Science (B.Sc., 3 years), Master of Science (M.Sc., 2 years), and Ph.D. (3 years). To promote student mobility, a system of academic credits (the European Credit Transfer System) has been recommended.

Traditional, course-based approach of university education is based on lectures and exercises offered each semester according to a curriculum schedule. Most courses end with an examination. At some universities, two or three weeks of field work take place at the end of spring semesters.

In 1970's, a new approach, - the problem based, or project based learning (PBL) was introduced and successfully implemented at the Aalborg University in Denmark and the University of Aveiro in Portugal (offers a B.Sc. education in Geo-information Engineering). In this educational model, lectures and exercises still have an important role but take less time (about $50 \%$ ). Main focus is on project work. Students have to find, define, and solve a problem within the course of the semester. Their work is documented in a report and defended during the examination. The concept of the PBL is to establish a closer connection between research and education. Teachers inform students about the latest developments during lectures and propose projects that are connected to their research topics. Supervising projects outside the educator's main research interest forces the teacher to update his knowledge in a broader context. 


\section{Examples of Study Programmes in Geoinformatics}

Education in Geoinformatics differs from institution to institution, depending on scientific profiles of teachers and researches, traditions, resources, equipment, and capacity. Three examples shown bellow illustrate show some of these differences. It is possible to compare how these Universities reflect challenges mentioned in chapter 2.

\section{Aalborg University}

Aalborg University (AAU) provides the sole educational program for chartered surveyors in Denmark. Education is carried out at the Faculty of Engineering and Science, Department of Planning and Development. There are three research groups responsible for curricula in land surveying, - Geoinformatics, Spatial Information Management, and Land Management. Prior to 2005, a one-level master degree programme was offered. Following-up recommendations of the Bologna agreement, a new study programme in chartered surveying has been established. The structure of this new programme is shown on Figure 1 (AAU_CS 2006). Student enrolment amounts to 20-40 students annually.

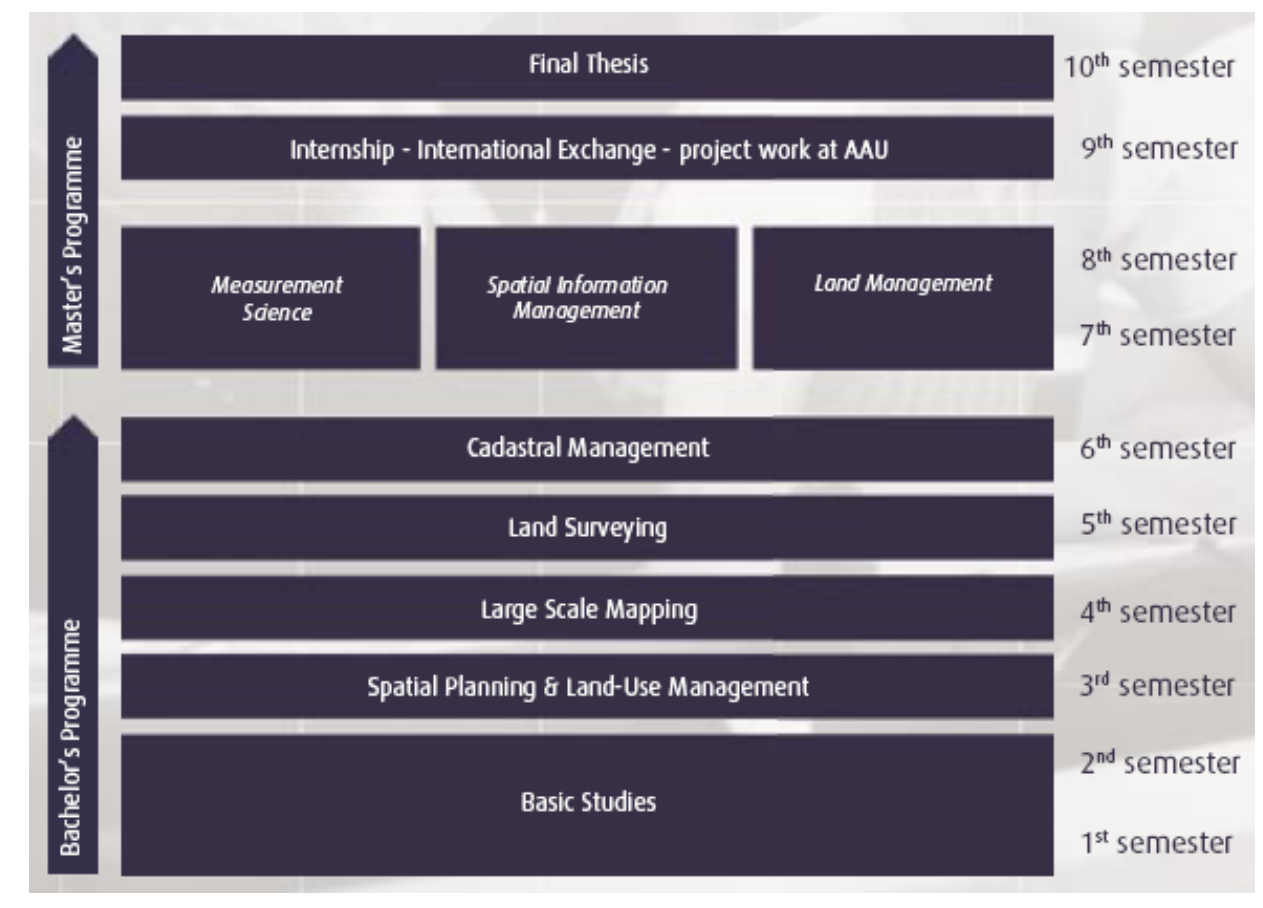

Figure 1: Structure of the chartered surveying study programme at AAU

During the first year of the Bachelor of Science programme, students gain knowledge in mathematics, computer science, GIS and also learn principles of Project Based Learning. It is the educational model at the AAU since its foundation in 1974. Groups of 5-7 students work on assigned projects starting in the first semester. Main topics of the 3rd to 6th semesters are Spatial Planning and Land-Use management, Large Scale Mapping, Land Surveying, and Cadastral Management. Students learn planning of urban and rural areas, land management, Cadaster, GIS, terrestrial measurement, GPS, photogrammery, cartography (map 
projections) and principles of adjustment theory. Assignments and projects reflect common tasks of land surveying practice.

Students can later choose one of three specialisations in the Master of Science programme. Overview of the specializationes and some of the courses offered in the 7th and 8th semester is given in Table 1. At the end of each semester, groups of 3-4 students present projects on a chosen topic within the theme of the semester as part of the examination. Examinations are only from subjects relevant to the project. The 9th semester provides the possibility of professional development according to the students' choice. Students can study abroad, undertake project work in the private sector, choose other courses at the AAU within the Master of Science programme, or start the final project. The study is concluded by an examination which includes defense of the final project, typically completed during the 10th semester in groups of 2-3 students. Examples of recent projects include mapping from high resolution satellite images, mobile mapping using a linear laser scanner and determination of volumes by laser scanning data.

\begin{tabular}{|c|c|c|c|}
\hline Specialisation & $\begin{array}{l}\text { Measurement sci- } \\
\text { ence }\end{array}$ & $\begin{array}{l}\text { Spatial Informa- } \\
\text { tion Management }\end{array}$ & $\begin{array}{l}\text { Land Manage- } \\
\text { ment }\end{array}$ \\
\hline Theme & Positioning & $\begin{array}{l}\text { GIS Theory and } \\
\text { Technology }\end{array}$ & Real Estate \\
\hline 7th s. & $\begin{array}{lr}\text { Surveying } & \text { and } \\
\text { Terrestrial } & \text { Laser } \\
\text { scanning, Global } & \text { Sositioning } \\
\text { Pys- } \\
\text { tems, Advanced } \\
\text { Photogrammetry, } \\
\text { Adjustment Theory, } \\
\text { Statistics, Spatial } \\
\text { Data Libraries } \\
\text { \& Data Quality, } \\
\text { Methodology \& Sci- } \\
\text { ence Theory, System } \\
\text { Development, Free } \\
\text { Study Activity }\end{array}$ & $\begin{array}{l}\text { Geospatial Analysis } \\
\text { I, Geocommunica- } \\
\text { tion I, Data Security } \\
\& \text { Copyrights, Spa- } \\
\text { tial Data Libraries } \\
\& \text { Data Quality, } \\
\text { Methodology \& Sci- } \\
\text { ence Theory, System } \\
\text { Development, Digi- } \\
\text { tal Administration }\end{array}$ & $\begin{array}{l}\text { Property Law, Prop- } \\
\text { erty Economy, Land } \\
\text { Administration Sys- } \\
\text { tems, Legal Aspects } \\
\text { of Land Adminis- } \\
\text { tration, Property } \\
\text { Valuation, Spa- } \\
\text { tial Data Libraries } \\
\text { \& Data Quality, } \\
\text { Methodology \& Sci- } \\
\text { ence Theory, Digital } \\
\text { Administration }\end{array}$ \\
\hline 8th s. & $\begin{array}{l}\text { Sensor Integration } \\
\text { in Surveying, Sen- } \\
\text { sor Integration in } \\
\text { Photogrammetry } \\
\text { \& Remote Sensing, } \\
\text { Data Integration \& } \\
\text { Image. Analysis, } \\
\text { Coordinate Trans- } \\
\text { formation, Object } \\
\text { Modelling rrom } \\
\text { Laser Scan Point } \\
\text { Clouds, Free Study } \\
\text { Activity }\end{array}$ & $\begin{array}{l}\text { Geospatial Analysis } \\
\text { II, Geocommuni- } \\
\text { cation II, GIS/IT } \\
\text { Implementation, } \\
\text { Social Aspects of } \\
\text { GIS, Standards \& } \\
\text { Exchange Formats }\end{array}$ & $\begin{array}{l}\text { Urban Management, } \\
\text { Local planning, Ur- } \\
\text { ban Growth Man- } \\
\text { agement, EU Legis- } \\
\text { lation, Legal Sociol- } \\
\text { ogy Nature \& Envi- } \\
\text { ronment Protection }\end{array}$ \\
\hline
\end{tabular}


Two teachers usually supervise the projects. One or two other teachers from AAU, experts from private sector or other universities together with supervisors examine the students. Cooperation with experts from private companies and other institutions ensures that the quality of education of the future graduates' meets the needs of the job market. Students evaluate each course at the end of the semester and provide their views on course contents, teacher's approach to the subject and students, teaching methods etc. to the Academic Board. All chartered surveying courses are taught in Danish while discussions on the possibility of teaching in English are ongoing. Information about the study programmes within the Department of Development and Planning is available from the AAU homepage (AAU_D 2006).

\section{ITC}

The Institute was established in 1950 in Enschede, the Netherlands, as the International Training Centre for Aerial Survey. Research, education, and project services are provided by six departments:

- Department of Earth Observation Science

- Department of Geo-information Processing

- Department of Urban and Regional Planning and Geo-information Management

- Department of Natural Resources

- Department of Water Resources

- Department of Earth Systems Analysis

The main mission of the ITC is 'directed at capacity building and institutional development for and in countries that are economically and technologically less developed', (ITC 2006). Over 17000 students from over 165 countries have completed educational programmes at the ITC since its foundation.

ITC offers courses in six specialisations:

- Geoinformatics

- Geo-information Management

- Urban Management

- Natural Resource Management

- Water Resources and Environmental Management

- Applied Earth Sciences

It is possible to choose from a number of courses in programmes of various durations and obtain certificates, diplomas and University degrees. Short courses and individual modules, undergraduate and postgraduate diploma courses, master courses and Master of Science courses, distance, or refresher courses are offered. To have a comparison with study programs at the other two universities, the M.Sc. degree course in Geoinformatics is shown as an example. 
Duration of the M.Sc. is 18 months and main topics of study, taught in six programme modules are:

- Generation of framework data

- Visualisation and dissemination of geospatial data,

- Design and optimisation of production and dissemination systems,

- Spatial information theory,

- Information extraction,

- Web technology for GIS and mapping

Two additional modules focus on research methods. Students may also choose three elective modules within their field of their interest from various modules offered by the six departments. The last six months are dedicated to work on Master thesis. English is the official language at the ITC. Detailed information can be obtained from the ITC's homepage (ITC 2006).

\section{Charles University in Prague}

Education in Geoinformatics is offered at the Faculty of Science, Department of Applied Geoinformatics and Cartography (CU_GIS 2006). The Department is a part of the Institute for Geography and its new curriculum was established in 2003. Since 2005/2006, new bachelor and master study programs have been established. The bachelor degree programme 'Geography and Cartography' educates students in the field of geography, GIS, and Remote Sensing. Students choose their bachelor thesis according to their interest in the field of physical geography and geo-ecology, social and regional geography, geoinformatics or cartography. The Bachelor study is concluded by the defence of a bachelor thesis and the bachelor State examination.

Students enrolled in the master degree programme 'Cartography and Geoinformatics' must pass an entry examination and are tested in their knowledge in Cartography, Remote sensing, and GIS. They have to demonstrate motivation for study and research and propose a possible topic of their master thesis. It is expected approximately 20 students enrol in the programme each year. Overview of master courses is given in Table 2. Students are trained in research of the given problem and finding their own solution as part of mandatory and elective labs and exercises. Emphasis is on a scientific approach, literature reviews and research of other sources of information, formulating problems to be solved and looking for optimal solutions to the defined problems. During the 9th and 10th semesters, students work on their master thesis. Their chosen topic fits their interest but its content and goals have to be approved by the thesis supervisor and the department head. The student has to defend the thesis and pass the final, State, examination. 


\begin{tabular}{|l|l|}
\hline Semester & Courses \\
\hline \hline 1 st & $\begin{array}{l}\text { Science Theory, Modern Cartographic methods, Extrac- } \\
\text { tion of Topographic Information }\end{array}$ \\
\hline 2nd & $\begin{array}{l}\text { Application of GIS, Extraction of Information from RS } \\
\text { Data, Interactive Maps, Theory of Spatial Information }\end{array}$ \\
\hline $3 \mathrm{rd}$ & $\begin{array}{l}\text { Database Design and Management, Web in GIS and } \\
\text { Mapping }\end{array}$ \\
\hline 4 th & Diploma seminar \\
\hline Elective courses & $\begin{array}{l}\text { Remote Sensing and Natural Resources, History of Car- } \\
\text { tography, GPS, Remote Sensing Project }\end{array}$ \\
\hline
\end{tabular}

All courses in the bachelor and master programme consist of lectures and practical exercises. Exercises are mostly held in computer rooms where students are asked to solve different tasks using available software packages. These tasks are more complex in Master courses and usually require two to three weeks to complete. Submission of all completed exercise tasks is the prerequisite for being admitted to an examination of the specific subject. To date, all courses are taught in Czech while a proposed study plan for international students, in cooperation with other universities is discussed.

\section{e-Learning}

New means of communication and information exchange via the Internet impact Geoinformatics education. Presentations complemented by lecture notes (e.g. PowerPoint slides) on the Internet are expected by students nowadays. Exercises, test questions and assignments are placed on the Internet and answered via the Internet. Students and teachers can communicate via electronic conferences, chat rooms and discussion boards and receive feedback to their work on-line. e-Learning programs can be used as supplementary study and training materials to lectures and exercises of existing courses. This is called the blended learning technique and may bring higher efficiency and better results to the learning process. All these tools are necessary for distance education and increase in significance in the lifelong learning programmes.

Software packages such as Moodle, BlackBoard, WebCT enable efficient implementation of eLearning courses. First, available tools for creating the course structure (setting the modules, calendar of events) are used. Second, the content of the course is defined (e.g. attaching different documents, linking external web-sites). Third, tools for checking the progress of students is added (multiple choice tests, assignments). Fourth, communication tools enable discussions between the teacher and student and among students.

e-Learning is one of topics discussed by education commissions of professional organisations such as ISPRS, ICA, or EuroSDR. For example, the EuroSDR activity 'EduServ', EuroSDR's education service, is offered to participants from national mapping and cadastral organisations, universities and the private sector. Since 2002, some 3-4 e-Learning courses reflecting the latest development in the field of spatial information sciences have been developed. Main the topics usually correspond to recent EuroSDR projects. Participants first meet teachers and other participants via an introductory seminar. e-Learning courses take 2 weeks per topic. During these two weeks participants study course materials, check the progress in their 
learning by self-tests, communicate with teachers and other participant in the course. At the end of the course they are asked to download, complete and submit a written assignment. After a successful completion of the course, the participant obtains a diploma.

EduServ is an example of a programme which contributes to continuing professional development. Development of e-learning courses, developed for a Master or Bachelor programmes, or as a form of distance learning, is a time consuming proposition. It should be re-usable in other courses and easily updated and function for a time period long enough to recover some or all of the creation costs (Mooney and Martin, 2004).

\section{Conclusion}

New curricula in Geoinformatics education have been established during the past few years. Their changes reflect new technological developments and needs of the society where emphasis is on applications in environmental sciences, land management, urban planning, natural resource management etc. Graduates should have a good knowledge of theory and methodologies used in spatial data acquisition, processing, analysing, and management.

Nowadays learning does not end by graduating from a university. New graduates must keep their life-long knowledge up-to-date. This presents a challenge to universities as new courses reflecting recent research and development at both undergraduate and graduate levels are required by the student and professional geoinformatics community.

\section{References}

1. Enemark, S.(2005): Global Trends in Surveying Education: and the role of the FIG, Azimuth Vol. 43, Nr. 3, pp. 19-21, ISSN 0728-4586

2. Höhle, J.(2006): Education and Training in Photogrammetry and Related Fields - Remarks on the Presence and the Future, International Archives of Photogrammetry, Remote Sensing and Spatial Information Sciences, Commission VI, 9.p (to be presented at symposium "E-Learning \& the Next Steps for Education", will be published in summer 2006)

3. Konecny, G.(2002): Recent Global Changes in Geomatics Education, International Archives of Photogrammetry, Remote Sensing and Spatial Information Sciences, Commission VI, Vol. XXXIV, Part 6, 6p.

4. Mooney, K., Martin, A.(2004): The potential of eLearning in the Spatial Information Sciences a Resource for Continuing Professional Development, International Archives of Photogrammetry, Remote Sensing and Spatial Information Sciences, Commission VI, Vol. XXXV, Part 6, pp. 160-162

5. AAU_CS $2006^{1}$

6. AAU_D $2006^{2}$

\footnotetext{
${ }^{1}$ http://www. landinspektor.dk/

${ }^{2}$ http://www.plan.aau.dk/indexuk.php
} 

7. AAU_L $2006^{3}$
8. CU_GIS $2006^{4}$
9. ITC $2006^{5}$
10. Wikipedia ${ }^{6}$

\footnotetext{
${ }^{3}$ http://www. lsn. aau.dk

${ }^{4}$ http://www . natur.cuni.cz/gis

${ }^{5}$ http://www.itc.nl

${ }^{6}$ http://en.wikipedia.org/wiki/Main_Page
} 